\title{
Educators and Education at a Crossroad in Bhutan
}

\author{
Yezer \\ Sherubtse College, Royal University of Bhutan, Kanglung, Trashigang, Bhutan
}

\begin{abstract}
This paper discusses the much contested issue with regard to the social status and work conditions of educators and examines whether decline is inevitable or can be reversed. Many teachers are in view that their status in the society is low and their profession is not respectable compared to the other professions. Mostly teachers and school administrators were interviewed to uncover their views about the status of teachers in the society. It was found out that both status and image of the teachers in the society are low compared to the other civil servants. There are issues in the schools of teacher shortage and also visible trend that many teachers left the teaching profession within the last one decade.
\end{abstract}

Keywords: Education, Teacher, Status, Policy,

\section{Introduction}

This paper provides an analysis of the societal status and working conditions of teachers in the schools. Factual evidence shows that many teachers are quitting their jobs. Some reasons mentioned on why teachers leave their profession refer to poor incentives, work overload, no real possibilities for advancement or future career and deteriorating work conditions. The Ministry of Education (MoE) is facing acute shortage of teachers and it seems that the teaching profession has become less attractive as people who do not top the Royal Civil Service Commission Examination score board chose teaching

https://doi.org/10.47852/bonviewCETR2020010202

This is an open access article published by the BON VIEW PUBLISHING PTE. under the Creative Commons Attributions License. 
as the second or even last best option. They are simply not qualified for anything else than teaching colleges. This is why the MoE has had great difficulty recruiting and retaining skilled and experienced personnel in the teacher's colleges and in the education system as such.

Taking these facts into consideration it may be perceived that teachers in Bhutanese society have lost their long-held status as one of the most important political and cultural symbols and denominators of both tradition and social privilege. Before, the teacher or the Lama was devoted, revered and respected with high social positions and privileges (Ura, n.a, p.102 \& 111).

In 2019, there were about 8,518 teachers in government schools and about 761 teachers in private schools across the country (Ministry of Education, 2019).

\section{Method}

The methodology applied is partly based on Max Weber's notion about status and stratification and partly on a qualitative approach where about 20 face-to-face interviews have been conducted which comprises officials from the Ministry of Education, Districts Education officers, principals and teachers from four districts - Thimphu, Bumthang, Sarpang and Trashigang. The researchers asked open-ended questions about the interviewees' perception regarding the social status and the working conditions of the teachers. The informants provided anonymously their own views and experiences. To supplement the analysis, government documents, media and scholarly work have been used as secondary data sources.

\section{Education in Bhutan}

The history of modern education in Bhutan goes back to 1960s when the country broke out from its self-imposed isolation. Since then government has put a concerted effort to provide free education to all citizens up to the basic level of class 10 and from 2018, the level had raised to class 12 . At the tertiary level the government provides scholarships based on merit.

There are two types of education system in Bhutan: the monastic and modern. Although, Denman and Namgyel (2008) assert that at the initial stage there was an intimidating conviction about the introduction of modern educational system, however at present it has become instrumental for socioeconomic development of the country.

The government gives emphasis on the education sector basically "... to improve happiness and life satisfaction in Bhutanese society, the education sector ... receive high priority" (Gross National Happiness Commission (GNHC) (2009a, p.119). Noticeably over the years, the number of schools and students have increased dramatically from 11 primary schools in 1959 to 491 schools and 440 to 
153740 students today (RGoB, 2008a \& MoE, 2019).

In 2018 , from the total of 28,618 civil servants in the country teachers considered to be the highest in number with about 32 per cent (Royal Civil Service Commission, 2018). Schools need adequate teachers and support staff if the quality of education is considered. The quality of education is determined by the quality of teachers and other educational resources. Thus, in order to attract the qualified teachers and upgrade their knowledge and skills, the MoE needs to work on to uplift the status of teachers.

In 2019, salaries of the teachers and medical professionals were increased higher than the other civil servants by looking at their workload and to deliver quality services. On this note Lyonchhen said, "As pledged, our focus is on according due motivation to the teachers, while also improving quality of the profession, which in turn will benefit our education system. Salary is just one aspect. As part of our flagship programs, we are also targeting capacity building and career advancement for teachers" (The Bhutanese, Para. 21).

However, teacher attrition rate seems to be high in the MoE. As of May 2019, about 480 teachers left the system (MoE, 2019). Therefore, the status of the teachers needs to be looked into critically in Bhutan.

\section{Education Policy}

The general policy of education is governed by the unique philosophy of GNH, Bhutan 2020, and MDGs as education is imperative for the development of the country. The education policy will determine the destiny of the country as the future citizens will be the product of the education system. Therefore, it is aptly mentioned in the planning vision document 'Bhutan 2020' (RGoB, 1999) that future education policy should be prioritized generally in improving access and quality of education under the broad objectives: holistic concept that innate potentials of each and every child is fully realized; inculcate traditional and cultural values; prepare students for the world of work with sense of dignity of work; create awareness about the importance of agriculture to allow options to become educated farmers; Bhutanization of the school curriculum and expansion of technical and vocational training programme for school dropouts. Bhutanization, in this context, means a radical reform of the schooling system from Indian to Bhutanese system by adding what the government perceived to be relevant Bhutanese values and principles. It is also a government standardization of the school curriculum and make education suitable for citizens. Another goal for education also stated as 'wholesome Education', in which it prepares student to become responsible, mature, and productive citizens to uphold pride of the nation and their parents. Therefore, the role of education focuses on 
youth to acquire appropriate knowledge, skills, attitudes and values which include achieving a layer of GNH goals (UNESCO, 2011).

In this context, the government decided that investment in education has both immediate and long term benefits. Education is considered the main driver for economic growth and poverty reduction, and therefore, vital for the achievement of HM the King's claimed goal of economic self-reliance. With this reason, throughout its FYPs, the education sector has always received high priority both in budget allocations and implementation of activities.

One of the main challenges to policy implementation is enhancing the overall quality of education but also improvement of access of education in remote areas needs to be intensified. The difficult terrain and extremely dispersed population have been the major obstacles to extend balanced education facilities across the country. Another challenge is the shortage of recruitment and retaining of teachers. Therefore, a suitable policy and planning intervention is required to deliver efficient and much better quality of social services to wider population in order to achieve its overall objectives.

\section{Teacher Development and Retention Policy}

Two new initiatives launched by the government clearly illustrate that there is a growing awareness of the increasing problems among teachers' morale and motivation. These initiatives also show an emerging understanding of the problems involved in the extreme version of a vertical topdown approach and an almost technocratic 'instalment of policies from above' and the fact that there is a lack of horizontal autonomous links among teachers themselves like professional trade unions or associations which could have acted as networks and fora for discussion and debate of frustrations and demands among the employees of this profession.

In order to attract and motivate the teachers, the MoE has launched Teacher Human Resource Policy, 2014 with the main purpose to (2014, p.3):

- "attract and retain the best and the brightest into teaching profession;

- see teaching profession as a career choice;

- create enabling environment to enhance the morale and motivation of teachers; and

- promote and strengthen fair and transparent human resource management".

In the similar context, in July 2019, the Government of Bhutan also increased the salary and allowances up to 55 percent to the teachers (Ministry of Finance, 2019).

With this policy in hand, it is anticipated that all teachers should benefit and in turn, improve the quality of education and make it more attractive to enter this profession. Today, 30 per cent of the total population are students and the numbers seem to be increasing. 
Royal Education Council (2010, p.3) proposes policy guidelines based on a strategic plan to attract, recruit, develop and retain the right teachers to deliver quality education. The framework for such policy is called 'GROW' which means “...ensure the professional Growth of the Bhutanese teachers, through better Recognition and opportunity, while seeing to their Well-being”. The detailed framework for GROW is given below

Figure 1. Source: Royal Education Council (2010).

\section{GROWTH \\ (through Enhanced Support for Professional Development)}

- More scholarships, etc, to help teachers upgrade themselves academically

- Core competency training

- IT-enabled \& Onsite Professional Development provisions

- Professional Learning Communities

- Protected Professional Development Time

- Structured Programme for Beginning Teachers

- Forming Equal Partnerships with Colleges of Education (CoEs) for PD

- Professional Development Continuum with CoEs, Schools and other Professional Organizations

\section{RECOGNITION}

(through Salary Incentives and Rewards)

- Enhanced Performance Management System

- Merit pay increments and performance-based bonuses to replace fixed salary increments

- Performance bonus rates to differentiate the outstanding from the good

- Introduce various Award schemes

- CONNECT plan deposits

\section{OPPORTUNITIES \\ (for Career Development)}

- Differentiated Career Tracks with enhanced opportunities for promotion

- Identifying and developing potential teachers for leadership positions

\section{WELL-BEING}

- Deployment of trained support and paraprofessional staff to ease teachers' non-core workload

- Part-time teaching scheme to support teachers with family commitments

- Support formation of Professional Associations to enhance professional image, development and well-being of teachers

- Engage media and other stakeholders in positive image building exercise

- Giving priority to Rural Schools' Teachers' children to attend boarding schools

- Comfortable Housing for Rural School Teachers

- Enhancing working environment 


\section{Teaching Profession}

According to UNESCO (1996, p.3) teacher means “... all those persons in schools who are responsible for the education of pupils". Teachers play a critical role in the life of students as "Teachers opening doors to a better world" (Education International, 2003, p.1). Therefore, teaching is a noble profession and service to the community and for nation building.

The teaching profession is important to build a better society and therefore, the career for the teachers must be made attractive. Education International (2004, p.1) states that "being attractive means offering adequate salaries and conditions of work". More than this, it is important to motivate future teachers by providing a sense of vocation and making their working conditions conducive. Many potential teachers are reluctant to take up this profession seeing the obstacles and frustrations experienced by today's teachers and they decide to look for jobs elsewhere. Such conditions also affect young teachers who may decide to change jobs after few years of service and this may also force experienced teachers to take early retirement or look for other employment. There is a teacher 'burn- out' situation prevailing all over the world. If serious steps are not taken by making the teaching profession more attractive and worthwhile - to retain and recruit quality teachers would be a great challenge and also the teacher shortage in developing and industrialized countries will persist or be rather aggravated (Education International, 2004). Therefore, it is important to take strong measures to retain qualified and experienced teachers and attract and motivate new young teachers (Education International, 2004). It is also important to ensure provision for good working conditions, social security and attractive salary higher than other profession (Education International, 2011). Government must pay attention for professional development of teachers and their incentives as teachers are the nation builders and they handle the most sophisticated life of children and young people.

\section{Bhutanese Perspectives on Teachers}

Officially, the government places highest priority to the quality of teachers, their morale and professional enhancement. It was re-emphasized during the celebration of 100 years of modern education in Bhutan, that enhancement of teachers' morale and motivation will lead to improve teacher satisfaction and improve quality (MoE, 2012). Seeing the importance of the teachers, Fourth King commanded

to achieve the objective of giving our children good education and productive jobs, there is a need to review the policy of education and refine them wherever necessary ...Amongst various steps, the most important step of developing the system of education is to promote our teachers. Therefore, 
the pay and allowances of our teachers should be increased to solve the urgent problem of shortage of teachers (Tobgay, n.a, p.7).

The Fifth King of Bhutan assures to the teachers "I will give you more importance and more recognition than any other sector ... having good teachers is most important" (Wangdi, 2012, p.1).

Therefore, teachers are backbone of the education system as shared by Karma (2014) in Pelden (2014). The Mckinsey and Company has studied 25 school systems from 2006 -2007 including 10 of the top global performers and found out that "the main driver of the variations in student learning at school is the quality of teachers" (Education Sector Review Commission, 2008, p.53). Teachers are, therefore, the heart of the education system.

Teachers are given due importance by every section of the society however, there needs an improvement in motivation and morale of the teachers because teaching profession has never been an attractive job in Bhutan. There is always the challenge to recruit a good teacher albeit government is trying to provide whatever possible support to teachers. It is mentioned "no financial incentive will be enough if measure in terms of the great responsibilities teachers shoulder since teaching is a daunting task ... sheer size of the teaching profession everywhere serves as impediment for more financial incentives" (Dema, 2010, p.1). Even then they have the largest share in public expenditure. However, "...effectiveness of the teaching force is influence by the recruitment, preparation, motivation and deployment process used by the education system" (South Asia: Human Development Unit, 2009, p.26). Hence, it is important to recognize the teachers' educational and training qualifications, their working environment, and commitment towards teaching as well as their identity as a teacher.

\section{Status and working conditions of Teachers}

There are debates on the status of teachers and what determines the status of teachers in general. UNESCO (1996, p.3) defines “...as evidenced by the level of appreciation of the importance in their function and of their competence performing it, and the working conditions, remuneration and other material benefits accorded them relative to other professional groups". Fwu and Wang (2002, p.211) defines social status of teachers as “... the relative standing of teaching as an occupation in a hierarchy of all occupations". Usually the occupation is determined by the prestige, wealth and authority but it may also vary comparatively in different societies of different countries (Fwu and Wang, 2002 cited from Biddle, 1995). There is notion that teachers' status should be higher than it is. Even teachers in America face challenges of low status. Falla $(2013$, p.1) asserts “...teachers often get a bum rap from parents, school administrators and even from politicians - when in reality the profession is a beleaguered one: teachers are overworked, underpaid and underappreciated". In the comparative studies 
conducted in England, Australia, New Zealand and the United Sates about the teachers' perceptions found that most teachers are satisfied with teaching aspects such as helping students to learn and modify their behaviours, but they are dissatisfied with factors such as inadequate compensation, stressful workload, increased community criticism and a poor public image of teaching (Fwu and Wang 2002 cited from Poppleton \& Risebourough, 1990; Harris \& Associations Incl., 1995; Dinham \& Scott, 1996, 1998, 1999, 2000). On the contrary, Fwu and Wang (2002) study reveals that in Taiwan teachers have occupational prestige as well as have respect from the society compared to their international counterparts. There are assumptions that relatively lower status may be due to the adverse social characteristics such as lower social origin, female dominance, the large size of the workforce, or the lower academic qualifications of teachers. Fwu and Wang (2002, p.214) cited from Hoyle $(1987,1995)$ and Poppleton (1999) mention that "the inferior public perceptions of teachers' role and the lower status of teacher training may also contribute to this unfavourable status". However, UNESCO (1996, p.4) has adopted guiding principles for the status of teacher as follows:

- The status of teachers should be commensurate with the needs of education as assessed in the light of educational aims and objectives; it should be recognized that the proper status of teachers and due public regard for the profession of teaching are of major importance for the full realization of these aims and objectives.

- Working conditions for teachers should be such as will best promote effective learning and enable teachers to concentrate on their professional tasks.

- Teachers organization should be recognized as a force which can contribute greatly to educational advance and which therefore should be associated with the determination of educational policy.

These recommendations intend to help the teaching profession to gain status and in turn, to benefit every child in the school to get quality education. However, it is also implied that the teachers should know their duties and responsibilities as they are part of the society.

MoE is facing teacher shortage even after producing more than hundreds of teacher-graduates every year from the two teacher training colleges (Samtse and Paro College of Education). There are instances where teachers either join other jobs or retire. With the resignation of 260 teachers in 2018 (MoE, 2019), the MoE still faced teacher shortage of about 400 teachers (Teacher shortage must be addressed, 2017). One World South Asia (2009, p.1) reports that “... various job vacancies advertised recently in the media, teachers made up about 80 per cent of the applicants ... A grade 7 teacher wanted to resign and join the Royal Privy Council as a personal assistant to a former minister". Due to the shortage of teachers some schools resorted to manage like 
Teachers were made to teach subjects that they were not trained in, which proved difficult for both teachers and students. As per the teacher guidelines, each teacher should teach 22 hours a week. But in DMSS [Dorokha Middle Secondary School], teachers on average have to teach 36 hours a week (Wangmo, 2013, p.1).

Despite all the measures the Ministry is trying to put in order to retain the teachers, more than 4 per cent of the teachers left the government schools for various reasons. Between 2008 to 2018, 1730 teachers have voluntarily resigned from the teaching profession. Since 2008, the attrition rate of teachers did not reduce drastically (MoE, 2018). The table below shows the number of teachers leaving the system annually:

Table 1.The Number of Teacher Leaving the System Annually

\begin{tabular}{|c|c|c|c|c|c|c|c|}
\hline Voluntary Year & Resignation & Compulsory Retirement & supernuation & Expiry of Contact & Others & Total & Attrition Rate(\%) \\
\hline 2018 & 263 & 7 & 60 & 10 & 15 & 355 & 4.02 \\
\hline 2017 & 260 & 4 & 56 & 9 & 16 & 345 & 3.99 \\
\hline 2016 & 200 & 6 & 42 & 31 & 11 & 290 & 3.5 \\
\hline 2015 & 142 & 1 & 27 & 3 & 25 & 198 & 2.5 \\
\hline 2014 & 115 & 2 & 21 & 1 & 40 & 179 & 2.0 \\
\hline 2013 & 134 & 5 & 27 & 86 & 9 & 261 & 4.0 \\
\hline 2012 & 156 & 3 & 71 & 19 & 15 & 264 & 4.0 \\
\hline 2011 & 125 & 1 & 25 & 101 & 20 & 272 & 4.0 \\
\hline 2010 & 144 & 10 & 15 & 1 & 111 & 281 & 5.0 \\
\hline 2009 & 125 & 3 & 8 & $\ldots$ & 18 & 154 & 3.0 \\
\hline 2008 & 66 & 5 & 13 & $\ldots$ & 18 & 102 & - \\
\hline Total & 1730 & 47 & 365 & 261 & 298 & 2701 & \\
\hline
\end{tabular}

Source: MoE, 2018, *others- death and termination

There are no concrete reasons mentioned in the report for the teachers to voluntarily resign. However, Pelden (2013, p.1) interviewed the former Education Minister Thakur S Powdyel and he expressed, "While remuneration may be a factor, it was not everything for teachers. What they're looking for isn't so much money as a sense of recognition and acknowledgement for the hard work that they do". This means teachers anticipate status and their work to be recognized. A female teacher, who resigned and joined a corporation expressed that

... her profession was not at all appreciated and that teachers received very little respect, despite 
working under poor conditions. It was not the pay that sent me packing but the stress, routine job and the fact that we were not appreciated for our service. There was also no room for professional and intellectual growth (One World South Asia, 2009, p.1).

Similarly Gurung (2012, p.1) shares:

In ten years of teaching career, I have grumble and have heard my colleagues grumble. But, interestingly, my observation has been that the grumbling was not so much about money or number of periods or the amount of extra work we had to do without money or recognition. The grumblings came when the system treated us unfair, and the society was ungrateful, when all our hard work was nullified and our conscience threatened.

The key factors for low teacher morale and motivation is pointed in Gyamtsho (2013, p.1) cited from Dorji (2006):

- heavy workload and disproportionate remunerations

- too much expectations with little support

- lack of recognition and acknowledgment

- unfair placement and training

- public image and social status

- lack of policy support

The ministry, however has shown concern and stated "the challenge for us is to help teachers regain their status in society and they need to be acknowledged" (One World South Asia, 2009, p.1). The ministry is working in every possible way to retain teachers and provide them opportunities for training and professional development.

Not only leaving from the job but the teaching profession remained as last priority for the job seekers. Choki $(2012$, p.1) reported that "[i]t's the same old story again. Teaching, the so-called "noble" profession does not have many takers in Bhutan with most university graduates placing the vocation last in their list of preferences." The teacher shortage has aggravated the working conditions of teachers especially in rural schools. The rural teachers are overburdened and felt neglected. They felt that incentives and training opportunities goes to urban teachers. "If nothing is done to curb this problem, the teaching profession will be the least preferred" as expressed by one of teachers in rural areas (Pelden, 2010, p.1). Similar problems are experienced in some of the urban schools as well. Teachers also felt that they have little time for other activities. "We don't get enough time to spend with our families; we have to engage ourselves in preparing lesson plans and correcting assignments and note-books of students" Choki (2012, p.1). It was reported by Rinzin (2018, para.9) that Individual Work Plan (IWP) has made teachers more overburdened than before as "... this has caused an overburden of workload 
because teachers have to keep records of other activities besides the daily lesson planning, book correction and preparation of teaching learning materials". However, compared to other civil servants, teachers are provided entitlement such as teaching allowance and others allowances. It was resolved in the National Assembly that the MoE was to study the possibility of increasing teaching allowance for teachers basically to encourage teachers in their profession and ultimately to improve the quality of education (Administrator, 2008). There is greater hope that the new 'Teacher Human Resource Policy 2014' may help to attract and retain more teachers.

\section{Status and working conditions of Teachers}

The general perceptions for the status of the teachers differ from place to place and society to society. Most of the principals shared that, "in the past teachers were regarded very high. Even our lord 'Guru Rimpoche' is called as guru meaning teacher. Even now they are regarded high in the rural areas because they are the main source of knowledge". This shows the level of status of the teachers varies as per location. However, they feel that the status of the teachers is deteriorating as society develops. As expressed by one of the principals "I feel teachers' image is going down because of globalization and development and our parents are also expecting too much now". There are also convictions that due to the high expectation from the society, they feel that the quality of education is deteriorating. Other principals have their views that teaching is considered as low-level profession because even "my students they don't want to be teachers". Many people have the notion that those who go for teaching have poor marks/ result in examinations. Some principals honestly expressed that currently there is no status for teachers in the society. These are the determining factors for the graduates who are reluctant to join the teaching profession as well as the present experience of the MoE to retain them. Many teachers leaving the teaching professional and joining other job could be one of the reasons where they feel teaching job is not respected like any other job. However, Minister of Education shares that "teachers are not motivated as of now; we are working on huge incentives package". One of the initiatives to motivate teachers could be 'Teachers Human Resources policy 2014'. "Our ministry is trying its best to uplift the morale of the teachers but we cannot say and predict the thinking of the people" (Principal). They expect the best policy to be implemented in order to uplift the morale of the teachers from society, so that quality education is imparted to our children.

\section{Working Conditions of the Teachers}

Regarding the working conditions of the teachers, many teachers felt that they are overburdened as they not only have to teach but they also have to hold many other additional responsibilities. The 
Chief Program officer, Youth Development Fund shares that "I agree that there is unhappiness in the district but at moment there is no alternative and all these programmes are beneficial for our students". However, ministry is concerned about the workload of teachers and currently they are working on teachers' workload ratio.

However, the Thimphu Thromdey Education Officer shares that if teachers manage their time properly, they are not overloaded. He said that teachers in Thimphu are not overloaded because there are enough teachers. On the contrary, in remote areas there are shortages of teachers that too with boarding facility where they have to work from 6 am to $9 \mathrm{pm}$. "Remote teachers take more than 24 periods in a week and do not have time to check students' notebook and plan lesson. Moreover, remote schools have large class size" (Thromdey Education Officer). In comparison, remote schools lack facilities where as urban schools enjoy adequate facilities. The working conditions of teachers are comfortable in urban than rural schools, this could be the one of the determining factors for teachers leaving the schools and joining other jobs available in urban areas. However, some of the teachers are happy to work in rural areas despite the series of challenges they face working in remote areas.

\section{Conclusion}

Generally, teachers are overburdened with many other activities besides teaching - some of these are planned and some adhoc. Further, their workload is aggravated by shortage of teachers coupled by the large class size. Compared to urban teachers, those teaching in rural areas are challenged by lack of facilities and also felt that they get less opportunity for professional development. Therefore, there is a need to have fair distribution of resources and opportunities for the teachers of remote schools. There is also the need to recognize and acknowledge the work and contributions of teachers so that they are motivated. Teachers must be empowered and given equal opportunity to grow professionally.

There is a feeling that the status of the teachers is low in Bhutan; moreover, teachers in urban places are least respected compared to rural. The factors for deteriorating the status of teachers could be modernization, perceptions of society towards teachers and also the government policy for recruitment of teachers. Teaching profession remained as last priority for the job seekers. Teaching profession is not considered as 'noble' profession rather it is treated like any other jobs. Moreover, there is no recognition for the teachers compared to other equivalent job. As a result, many young talented graduates are reluctant to opt teaching as their career. Increasing of teachers' salary is not only the factor to uplift their status in the society but there are other factors that need to be considered such as appropriate workload, recognition, acknowledgement, equal opportunity for professional growth, build image of the teachers in the society and best policy support. All these factors are important to be considered to enhance status 
of our teachers in the society which in turn will contribute to the nation building

\section{Reference}

[1] Administrator. (2008). Teachers' allowance to increase. Retrieved from http://bhutanobserver. bt/5998-bo-news-about-teachers_allowances_to_increase.aspx

[2] Choki, S. (2012). Teaching Considered "nobel" No More. The Bhutanese. April, 11, 2012. Retrieved from http://www.thebhutanese.bt/teaching-considered-noble-no-more/

[3] Dema,S. (2010). Ministers' Say on Teacher's Day, News Bhutan. Retrieved from http:// newsbhutan.blogspot.com/2010/07/minsters-say-on-teachers-day.html

[4] Denman, B.D. and Namgyel, S. (2008). Convergence of Monastic and Modern Education in Bhutan.

[5] International Review of Education, 54(3/4), 475-491. DOI 10.1007/s11159-008-9085-0

[6] Education International. (2003). Teachers Opening Doors to a Better World. Retrieved from http://download.ei- ie.org/Docs/WebDepot/(2003)\%20World\%20Teachers\%20Day\%20Statement\%20 en.pdf

[7] Education International. (2004). Quality Teachers for Quality Education. Retrieved from http:// download.ei- ie.org/Docs/WebDepot/(2004)\%20World\%20Teachers\%20Day\%20Statement\%20en.pdf

[8] Education International. (2005). Quality Teachers for Quality Education, Training for a Stronger Teaching Force. Education International/World Confederation of Teachers Joint Statement on World Teachers' Day 2005. Retrieved from http://download.ei- ie.org/Docs/WebDepot/(2005)\%20 World\%20Teachers\%20Day\%20Statement\%20en.pdf

[9] Education International. (2014). Teacher Education. Retrieved from http://www.ei- ie.org/en/ websections/content_detail/5528

[10] Education Sector Review Commission. (2008). Education without Compromise. Retrieved from http://www.camb-ed.com/Portals/0/Documents/Bhutan-Education-Quality-Survey--Educationwithout-Compromise-jan2008.pdf

[11] Fwu, B.J. and Wang, H.H. (2002). The Social Status of Teachers in Taiwan. Comparative Education.Vol. 30. No. 2. pp. $211-224$

[12] Falla, Y.J. (2013). The Low Status of Teachers: A Global Epidemic?. Retrieved from http:// www.smith.edu/insight/stories/teaching.php

[13] GNHC, (2012). Guidelines for preparation of the Eleventh Five Year Plan (201-2018). 
Thimphu: Royal Government of Bhutan.

[14] Gross National Happiness Commission. (2009a). Tenth Five year Plan 2008-201, Volume 1: Programme Profile. Thimphu: Author.

[15] Gurung, A. (2012). Teacher Motivation in Bhutan. Retrieved from http://pelkhil.edu. $\mathrm{bt} / \mathrm{p}=2692$

[16] Gyamtsho, S. (2013). Motivation can make a mule dance. Kuensel, October 28, 2013. Retrieved from http://www.kuenselonline.com/motivation-can-make-a-mule-dance/\#.Uy0QGqiSzc8

[17] HM assures teachers of more importance, recognition. (Friday, November16, 2012). Kuenselonline. Retrieved from http://kuenseleng.blogspot.com/2012/11/hm-assures-teachers-of-moreimportance.html

[18] Kempton, J. (2013). To teach, to learn: more effective continuous professional development for teachers. Center Forum. Retrieved from http://www.centreforum.org/assets/pubs/teacher-cpd- web. pdf

[19] Ministry of Education. (2019). Annual Education Statistics 2019. Thimphu: Policy and Planning Division.

[20] Ministry of Education. (2013). Celebration Sherig Century 100 years of Building the nation. Addendum to the fourth annual report of the Hon'ble Prime Minister to the Ninth Session of the First Parliament on The State of the Nation: Education. Royal Government of Bhutan.Thimphu.

[21] Ministry of Education. (2013). Annual Education Statistics 2013. Policy and Planning Division. Thimphu.

[22] Ministry of Finance. (2019). Notification. Thimphu: Royal Government of Bhutan. Retrieved from https://www.mof.gov.bt/wp-content/uploads/2019/07/PRABJuly2019.pdf

[23] One world South Asia. (2009). Teachers in Bhutan look for greener pastures. Retrieved from http://southasia.oneworld.net/news/teachers-in-bhutan-look-for-greener-pastures

[24] Pelden, S. (2013). High teacher dropout rate. Kuensel. October, 22 2013. Retrieved from http://www.kuenselonline.com/high-teacher-dropout-rate/\#.UyvgiKiSzc8

[25] Planning Commission. (1992). Seventh Five Year Plan (1992-1997). Thimphu: Royal Government of Bhutan.

[26] Phuntsho, K. (2000). On the Two Ways of Learning in Bhutan. Retrieved from http://www. bhutanstudies.org.bt/journal/vol2no2/v2/n2.learning.pdf

[27] Peldan, S. (2013). High Teacher dropout rate. Kuensel. Thimphu. Retrieved from http://www. kuenselonline.com/high-teacher-dropout-rate/\#.Uyg0faiSzc8

[28] Pelden, S. (2010). No Teacher shortage statistically. Bhutan Observer. September 24, 2010. 
Retrieved from http://bhutanobserver.bt/3255-bo-news-about-no_teacher_shortage_statistically.aspx [29] Rinzin, Y.C. (2018, May17). PM orders a review of IWP for teachers. Kuenselonline. Retrieved from http://www.kuenselonline.com/pm-orders-a-review-of-iwp-for-teachers/ [30] Royal Civil Service Commission. (2018).Civil Service Statistics December 2018. Retrieved from https://www.rcsc.gov.bt/wp-content/uploads/2019/05/CSS-2018-final.pdf

[31] Royal Government of Bhutan. (1999). Bhutan 2020: A Vision for Peace, Prosperity and Happines, Thimphu.

[32] Royal Government of Bhutan. (2013). The State of the Tsa-Wa-Sum. First Session of the Second Parliament of Bhutan, 30 September, 2013. Thimphu.

[33] Royal Education Council. (2010). Teacher Quality Enhancement Project, Policy Guidelines and Strategic Plan. Thimphu: Planning Commission Secretariat.

[34] South Asia: Human Development Unit. (2009). Findings from the Bhutan Learning Quality Survey. Report No. 21. Discussion paper series. Retrieved from http://datatopics.worldbank.org/hnp/ files/edstats/BTNstu07.pdf

[35] Tobgay, S. (n.a). Education System in Bhutan -Past, Present and Future, A Reflection. Retrieved from http://www.judiciary.gov.bt/html/education/publication/educationCJB.pdf [36] Teacher shortage must be addressed. (2019, August, 9). Retrieved from http://www. kuenselonline.com/teacher-shortage-must-be-addressed/

[37] The Bhutanese. (August 6, 2019). Revolutionary Hike: Education and Health wins as Teachers and Doctors are now the Highest Paid Civil Servants. Retrieved from https://thebhutanese.bt/ revolutionary-hike-education-and-health-wins-as-teachers-and-doctors- are-now-the-highest-paid-civilservants/

[38] UNESCO. (2011). World Data on Education, VII Ed. 2010/11. International Bureau of Edcation. Retrieved from http://unesdoc.unesco.org/images/0021/002113/211300e.pdf

[39] UNESCO. (2007). Operational Definitions of Basic Education: Thematic Framework. Retrieved from http://www.unesco.org/education/framework.pdf

[40] UNESCO. (1996). Recommendation concerning the Status of Teachers. Paris. http://www. unesco.org/education/pdf/TEACHE_E.PDF

[41] Wangmo, C. (2013). Severe teacher shortage in Dorokha MSS. Retrieved from http:// bhutanobserver.bt/7518-bo-news-about severe_teacher_shortage_in_dorokha_mss.aspx 